\title{
The Role of Information and Communication Technology (ICT) in Enhancing the Innovative Learning Process
}

\author{
Frans Adam ${ }^{1}$, Gilbert Ray ${ }^{2}$ \\ University of Singapore \\ Singapore \\ e-mail: frans.adam62@yahoo.com gilbertray65@yahoo.com
}

To cite this document:

Frans Adam, \& Gilbert Ray. (2020). The Role of Information and Communication Technology (ICT) in Enhancing the Innovative Learning Process. IAIC Transactions on Sustainable Digital Innovation (ITSDI), 2(1), 54-60.

DOI : https://doi.org/10.34306/itsdi.v2i1.352

\begin{abstract}
The most significant instruments in the learning cycle are the educator and learning media. Obviously, the utilization and choice of fitting instructional media completed by an instructor will have an impact on the cycle and consequences of the learning. For this situation, data and correspondence innovation based learning media is the most significant thing in the advancement of the universe of training. Data and Communication Technology (ICT) is a program for instruments, control and passing on of data and information to make it simpler in the learning cycle in the homeroom. With ICT-based learning media, understudies can create thinking abilities and improve instructor aptitudes expertly. Educators become more propelled and inventive in homeroom learning. The reason for this investigation was to decide the function of educators in utilizing learning media dependent on Information and Communication Technology.
\end{abstract}

Keywords: Learning Media, ICT, Teacher

The Role of Information and... 


\section{Introduction}

The advancement of Information and Communication Technology or ICT has encountered fast changes and upgrades over the most recent 10 years that have tremendously affected human life in different fields including business, diversion and instruction. The impact that can be felt is extremely clear in the field of training. We can perceive how the impact of ICT on understudy learning with bountiful wellsprings of data and changes in the manner every instructor educates to envision it. This doesn't make the difficulties looked by educators lighter, since understudies must have the option to rival worldwide ICT attributes.

As of now the instructor is not, at this point the focal point of learning assets and the primary transport of data, yet more than that, in particular having a function as a friend, coach and facilitator, and furthermore as an accomplice in creating understudy information and capacities. The utilization of ICT in training has colossal potential, to be specific to expand admittance to instruction, proficiency, and the nature of learning and educating. Moreover, on account of the imagination made by the educators, it gets the capability of ICT showing unique, dynamic, troublesome topics, just as capacities in liveliness and reproduction. Today we can likewise perceive how the obvious impact of ICT is in transit understudies and educators interface, mingle and speak with their companions. This will urge us to consistently adapt ceaselessly. Then again, the potential for ICT to be used in instruction arranging and the executives can't be overlooked.

The utilization of ICT is required to be improved by educators to encourage more inventive exercises in the learning cycle. Understudy focused learning procedures and techniques are truly reasonable to empower the advancement of understudy information and aptitudes. As per Wagner (2008), In this world wide world, understudies don't just need to know data and recall realities, however they should likewise have the option to think basically and tackle issues just as the capacity to impart. Furthermore, understudies should likewise have the option to adjust, have the option to investigate data and have high interest. With the capacity to utilize ICT and its application.

There are numerous exercises in instruction and training that educators can do with the assistance of ICT, including organization, correspondence, improvement of learning assets, making learning arrangements, conveyance of showing materials, assessment, exercises inside and outside the homeroom, autonomous learning, to instructor proficient turn of events. In any case, the ideal utilization of ICT in learning by instructors and understudies isn't simple. There are in any event three conditions that must be met, to be specific: (1) instructors and understudies must have simple admittance to innovation gadgets including an Internet association, (2) accessibility of advanced substance (instructing materials) that is simple for educators and understudies to get, (3) instructors must have the information and abilities to utilize innovation and assets to assist understudies with accomplishing scholarly norms.

\section{ICT development}

In the last 10 years, the development of ICT both in terms of hardware and software has been very fast. Generally, the development of these ICT tools leads to smaller forms, lower prices, increasingly powerful power, and increasingly integrated into everyday life. This can be seen for example laptop ICT devices or PCs on the market today tend to be smaller, cheaper but with better specifications than they were in previous years. With the availability of increasingly powerful tools, software makers are also encouraged to design displays and functions that make it easier for users to meet their daily needs.

According to the Gartner IT Research Institute, the trends in ICT development in 2013 include: cloud computing, mobile devices, social networking and big data. Cloud computing (cloud computing) is a new term that refers to the use of computing resources (hardware and software) as services accessed via the internet network. Over the last few years we have seen 
tremendous developments in cloud computing, such as the popular web applications VolP (eg, Skype, Google Voice), social networking applications (eg, Facebook, Twitter, Linkedln), media services (eg, Picasa, YouTube, Flickr), content distribution (for example, BitTorrent), financial applications (for example, Mint), and many more. Even traditional desktop software, such as Microsoft Office, has moved partly to the Web with its 2010 Office Web Apps.

Web applications are now shifting to become increasingly dynamic which emphasizes user interactivity, exchanging information in various media formats such as text, graphics, animation, audio, and video. The O'Rielly (2005) team popularized this new use of the web with the term Web 2.0. The rise of web-based applications that support collaboration and social networking should be used for learning as well. Now most of the teachers and students get their information from the Internet. Various well-known search engines such as Google and Yahoo are the main way to find this information.

Currently, almost all students access the internet every day. Even so, students need to understand that not all information obtained from the internet is valid and correct. The internet traffic density every day is extraordinary. As an illustration, according to Weiser (2012), in one minute 30 hours of video are uploaded on Youtube, 100 thousand tweet messages are posted, 6 million Facebook pages are viewed, 20 million photos viewed from Flickr, 47 thousand applications downloaded. In fact, Intel predicts, in 2015, 15 billion connected mobile devices will make the mobile Internet traffic density increase by 11 times.

Public acceptance of mobile ICT devices such as smartphones, tablets, etc. will slowly shift the position of PCs and laptops which have been seen as the main tools of ICT. Now many smartphones are more powerful than office and home PCs or laptops. Every appearance of a new gadget is welcomed by the wider community like hotcakes. So far, the use of these devices is still not optimal for learning, therefore the challenge going forward is how to develop learning content so that it is easily accessible by these mobile devices.

\section{The Role of ICT in Innovative Learning}

So far, teachers are expected to be able to carry out active, participatory and fun teaching and learning activities. Teachers have also known the term PAIKEM which stands for Active, Innovative, Creative, Effective, and Fun Learning. According to Endang (2010), this PAIKEM learning model describes the entire teaching and learning process that is fun by involving students to participate actively during the learning process. To be able to realize such active and fun learning, of course, it requires creative and innovative ideas from the teacher in choosing methods and designing learning strategies.

ICT can be applied innovatively at all stages of teaching and learning activities, starting from making learning plans, preparing materials, presenting materials, implementing learning, to evaluation. The essence of innovation is the existence of something new that is different from the usual (conventional). However, ICT does not necessarily apply to all things or all aspects of learning. For example in science or science learning (physics, chemistry, biology, etc.), by utilizing ICT the teacher can create animations or simulations to make it easier for students to learn abstract, dynamic concepts. as well as complex. However, to provide experience so that students can feel the warmth of the eggs that have just come out of the hen, of course it cannot be animated via computer.

Science learning in primary and secondary schools primarily aims to develop scientific process abilities (skills), encourage conceptual understanding and develop positive attitudes towards science (Murphy, 2006). Scientific process skills can be trained for example through observation, communication, measurement, experimentation, etc. Students also have to understand various basic concepts in science lessons such as the concept of time, weight, length, etc. Besides that, by learning science, students are expected to develop a positive attitude or commendable character such as responsibility, cooperation, honesty, etc. Learning approaches or strategies can change significantly if teachers make optimal use of ICT. What is the role of ICT in helping students develop these skills, concepts and attitudes? McFarlane 
(2000) illustrates the relationship between the use of ICT and the development of students' science skills in (Figure 1).

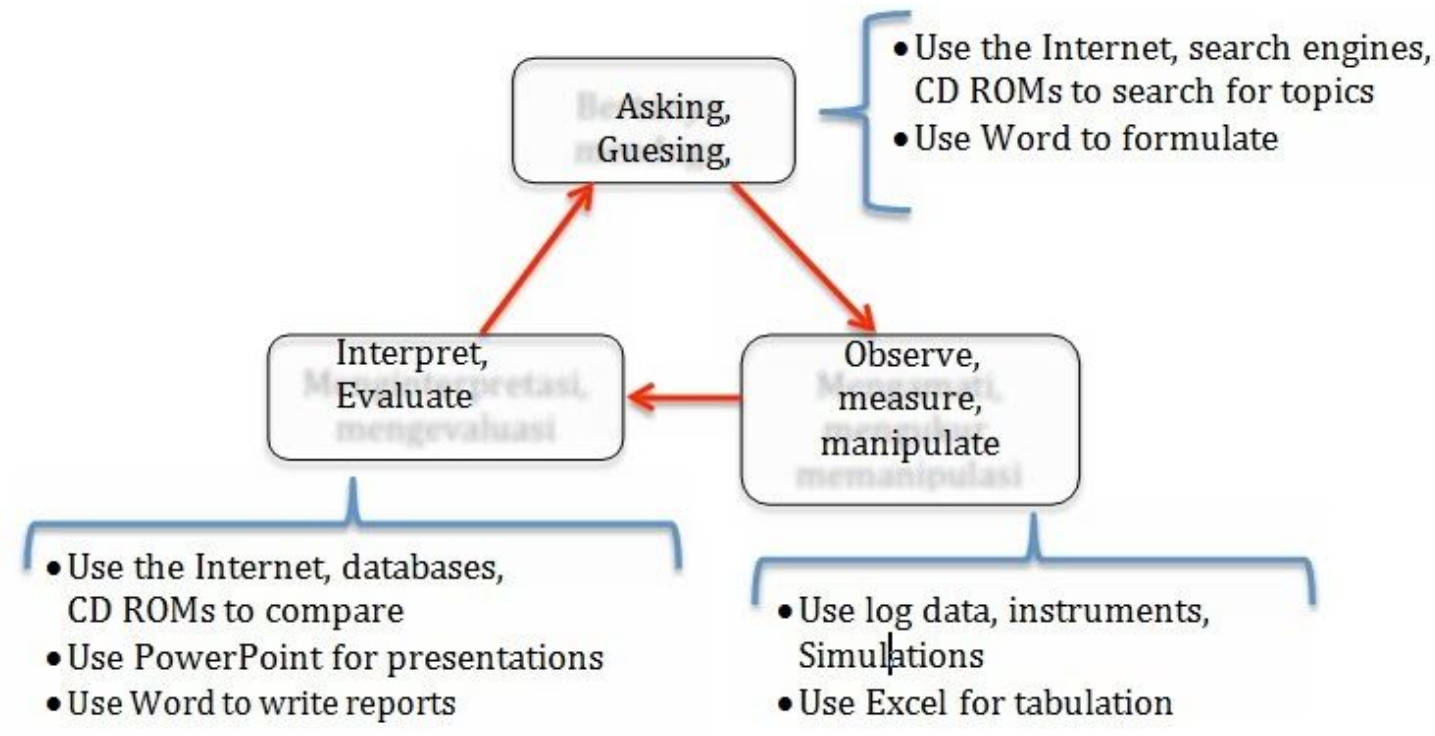

Figure 1. The relationship between the use of ICT and the development of students' science skills

The implication of using ICT in innovative learning is the acquisition of active, collaborative, creative, integrative, and evaluative learning (Shreya, 2012). ICT-enriched learning (for example: hypermedia, simulation) makes it easier for students to conduct inquiries and analyze new information. Students do not just memorize facts but are facilitated to construct new knowledge based on examples of everyday life, so that it becomes active and very interesting learning. ICT-supported learning (for example: discussion forums, chat, email) encourages students to interact and collaborate with fellow students, teachers and experts in relevant fields wherever they are. ICT-based learning (for example: simulations, games, animation) also provides facilities for students to manipulate existing situations and create creative and interesting products.

\section{Application of ICT in Learning}

The application of ICT in learning can be grouped into two categories: a) ICT as a tool and b) learning through ICT (Webb, 2002; Lavonen, etc, 2006). In terms of ICT as a tool, there are currently many software available on the market or on the Internet that can be used as a tool that allows students and teachers to complete their work efficiently. In making practicum reports, students can use a word processor, such as Microsoft Word or OpenOffice, to get better and faster results. Students can also supplement the report with relevant drawings made with either simple image processing tools such as Paintbrush and Photoeditor or advanced ones such as Photoshop, Coreldraw or Gimp. Tables for pouring practical data can also be easily and quickly created with a Number Processor such as Microsoft Excel or OpenOffice. Furthermore, students can present the results of their experiments in front of the class using presentation software such as Microsoft PowerPoint. On the other hand, teachers can too utilize these tools to make lesson plans, compile teaching materials, and present materials efficiently. 
In the second category, namely learning through ICT or learning facilitated by ICT can include the use of (a) CAL (Computer Assisted Learning), (b) CAI (Computer Assisted Inquiry), and (c) E-learning. CAL is a computer-based learning application where students can easily interact with computers to study learning material. Complex and abstract learning materials can be represented through multimedia such as animation and simulation so that students can easily learn them. Presentation of learning material that emphasizes the process or motion is implemented through animation. The animation that allows student intervention through direct interaction, for example by changing parameters, is called simulation. The role of multimedia, especially animation and simulation, is very important in learning, especially science lessons.

CAI (Computer Assisted Inquiry) is the use of ICT to help collect information and data from various sources to support scientific reasoning (McFarlane and Sakellariou, 2002). Here, ICT is used as an agent to interact with information sources such as the Internet or a Microcomputer based Laboratory. In science learning, computer-based models and simulations have an important role because they can simplify complex or abstract ideas, objects, events, processes, systems or scientific phenomena. Besides that, with a simulation in the form of a virtual experiment, students can carry out lab activities and obtain experimental data that is useful as material for further analysis and research.

Meanwhile, e-learning, which is becoming very popular because of its flexibility and effectiveness, is a way of delivering learning materials via the Internet. Through e-learning, learning materials can be accessed anytime and from anywhere. Besides, because the material can be enriched with various learning sources including multimedia and can be updated quickly by the teacher, then biology learning can also take advantage of the advantages of this e-learning.

Flexibility is the keyword in e-learning systems. Students become very flexible in choosing the time and place of study because they do not have to come in one place at a certain time. On the other hand, the teacher can update the learning material anytime and from anywhere. In terms of content, learning materials can be made very flexible, starting from text-based teaching materials to learning materials that are loaded with multimedia components. However, the quality of learning with e-learning is also very flexible or varied, which can be worse or better than face-to-face (conventional) learning systems. To get a good e-learning system requires a good design too.

In designing a good e-learning system, four things need to be considered, namely: instructional design, media, software, economics (Horton, 2006). E-learning design must start with a good instructional design, for example the formulation of goals, strategies, activities. Understanding the characteristics of students is very important, namely, among others, their hopes and goals in participating in e-learning, speed in accessing the internet or network, limited bandwidth, cost for internet access, and background knowledge regarding readiness to take part in learning. An understanding of the learning outcomes is needed to determine the scope of the material, the learning outcome assessment framework, and initial knowledge.

Furthermore, the selection of suitable media for biology learning materials needs to be selected, managed and presented properly. What is equally important is the selection of suitable software for creating e-learning and its contents. E-learning systems can be applied asynchronous, synchronous, or a mixture of the two. Examples of asynchronous e-learning are often found on the Internet, both simple and integrated through e-learning portals. Meanwhile, in synchronous e-learning, teachers and students must be in front of 
the computer together because of the process learning is carried out live, either via video or audio conference.

Furthermore, there is also the term blended learning, which is learning that combines all forms of learning, for example on-line, live, and face-to-face (conventional). The National Science Teachers Association (NSTA, 2008) supports and encourages the use of e-learning for Science learning. Several reasons, among others, because e-learning promises (a) more effective access to science concepts and teaching, especially when it comes to observation, measurement and scientific research, (2) the latest information related to science material and resources from the internet, (3) various animations and simulations related to science. However, this e-learning will be more optimal if it is applied together with other methods such as face-to-face activities between teachers and students and assignment activities outside the classroom.

\section{Conclusion}

The rapid development of ICT and easy access requires teachers to take advantage of the various advantages of ICT in innovative ways in learning activities both inside and outside the classroom. With good and innovative design, ICT can make Science learning materials interesting, not boring, easy to understand, and can be learned anytime and from anywhere. Blended learning, which is a combination of ICT (multimedia, e-learning), face-to-face (discussions, lectures), and independent (assignments, projects, labs) is considered the most likely form of implementation in Indonesia given the limited infrastructure.

\section{References}

[1] Cooney, (2011), Gartner: The top 10 strategic technology trends for 2012, Network World. http://www.networkworld.com diakses 25 September 2012

[2] Endang Mulyatiningsih. (2010). Pembelajaran Aktif, Kreatif, Inovatif, Efektif dan Menyenangkan (PAIKEM). Jakarta: Ditjen PMPTK.

[3] Fisseha Mikre (28 July 2011 ) The Roles of Information Communication Technologies in Education Review Article with Emphasis to the Computer and Internet, Ethiop. J. Educ. \& Sc. Vol. 6 No 2

[4] Horton, (2006), E--learning by Design, San Francisco: Pfeiffer

[5] Lavonen, etc. (2006) A Professional Development Project for Improving the Use of ICT in Science Teaching. Technology, Pedagogy and Education, 15(2), pp. 159--194

[6] McFarlane, A. (2000a) The impact of education technology, in Warwick, P. and Sparks Linfield, R. (eds) Science 3-13: The Past, The Present and Possible Futures. London: Routledge Falmer.

[7] McFarlane and Sakellariou (2002). The Role of ICT in Science Education, Cambridge Journal of Education, 32(2), pp. 221--232

[8] O'Reilly, (2005), What is Web 2.0, http://oreilly.com/web2/archive/what--is-- web--20.html. Diakses tanggal 29 September 2012

[9] Murphy, (2006), The Impact of ICT on Primary Science, New York: Open University Press. 
[10] NSTA, (2008), The Role of E--Learning in Science Education. http://www.nsta.org/about/positions/e--learning.aspx. Diakses tanggal 29 September 2012

[11] Shreya Vinay Patil. (2012). The Role of ICT in Educational Sector. Loka Vishkar International E--Journal, ISSN 2277--727X, Vol--I, Issue--IV, Oct--Nov-- Dec2012

[12] Wagner, Tony. (2008). The Global Achievement Gap. New York: Basic Books Webb, M. (2002). Pedagogical reasoning: Issues and solutions for the Teaching

[13] and Learning of ICT in Secondary School, Education and Information Technologies, 7(3), pp. 237--255 